This is the author's final, peer-reviewed manuscript as accepted for publication. The publisher-formatted version may be available through the publisher's web site or your institution's library.

\title{
Evidence based effectiveness of vaccination against Mannheimia haemolytica, Pasteurella multocida and Histophilus somni in feedlot cattle for mitigating the incidence and effect of bovine respiratory disease complex
}

\author{
R.L. Larson and D.L. Step
}

How to cite this manuscript

If you make reference to this version of the manuscript, use the following information:

Larson, R. L., \& Step, D. L. (2012). Evidence based effectiveness of vaccination against Mannheimia haemolytica, Pasteurella multocida and Histophilus somni in feedlot cattle for mitigating the incidence and effect of bovine respiratory disease complex. Retrieved from http://krex.ksu.edu

\section{Published Version Information}

Citation: Larson, R. L., \& Step, D. L. (2012). Evidence based effectiveness of vaccination against Mannheimia haemolytica, Pasteurella multocida and Histophilus somni in feedlot cattle for mitigating the incidence and effect of bovine respiratory disease complex. Veterinary Clinics of North America-Food Animal Practice, 28(1), 97106.

Copyright: (c) 2012 Elsevier Inc.

Digital Object Identifier (DOI): doi:10.1016/j.cvfa.2011.12.005

Publisher's Link: http://www.vetfood.theclinics.com/article/S0749-

0720\%2811\%2900079-X/abstract

This item was retrieved from the K-State Research Exchange (K-REx), the institutional repository of Kansas State University. K-REx is available at http://krex.ksu.edu 
Evidence based effectiveness of vaccination against Mannheimia haemolytica, Pasteurella multocida and Histophilus somni in feedlot cattle for mitigating the incidence and effect of bovine respiratory disease complex

R.L. Larson, DVM, PhD, ACT, ACVPM-Epi ${ }^{\mathrm{a}}$ and D.L. Step, DVM, ACVIM ${ }^{\mathrm{b}}$

${ }^{a}$ Professor, Coleman Chair Food Animal Production Medicine, Department of Clinical

Sciences, College of Veterinary Medicine, Kansas State University, Manhattan, Kansas

${ }^{\mathrm{b}}$ Professor, Department of Veterinary Clinical Sciences, Center for Veterinary Health

Sciences, Oklahoma State University, Stillwater, Oklahoma

The authors have nothing to disclose.

Keywords: Evidence-based, bovine respiratory disease complex, Mannheimia haemolytica, Pasteurella multocida, Histophilus somni, vaccination

\section{Contact Information:}

\begin{tabular}{|l|l|}
\hline $\begin{array}{l}\text { a Corresponding author for } \\
\text { proof and reprints: }\end{array}$ & b Coauthor address: \\
\hline Robert L. Larson, DVM, PhD, ACT, ACVPM-Epi & Doulas L. Step, DVM, ACVIM \\
Department of Clinical Sciences & Department of Veterinary Clinical Sciences \\
College of Veterinary Medicine & Center for Veterinary Health Sciences \\
Kansas State University & Oklahoma State University \\
1800 Denison Avenue & 002 BVMTH \\
Manhattan, KS 66506 & Stillwater, Oklahoma 74078 \\
785-532-4257 (phone) & $405-744-8578$ (phone) \\
785-532-4989 (fax) & 405-744-6265 (fax) \\
RLarson@vet.k-state.edu (email) & dl.step@okstate.edu (email) \\
\hline
\end{tabular}




\section{INTRODUCTION}

Evidence-based medicine (EBM) was introduced to the medical literature in a 1992 article by the Evidence-based Working Group at McMaster University Health Sciences Centre in Canada to describe the clinical learning strategy they had been developing for over a decade.[1] The principles of EBM are being applied to the veterinary profession under the term evidencebased veterinary medicine (EBVM).[2-4] The underlying concepts of EBM and EBVM are rooted in clinical epidemiology and are not new, but are a formal and explicit effort to increase the occurrence of basing clinical decisions on a dispassionate review of published trials that adequately meet a priori standards of experimental design and experimental execution.

Although most clinical decisions in veterinary medicine are based on evidence of some type, some evidence is very strong (rigorously tested in the target species under natural conditions (e.g. cattle in commercial feedlots) in experiments designed to prove a theory to be false), some evidence is very weak (not tested), and some is intermediate.[5-7] The hierarchy of evidence is based on the strength of evidence for causation, the ability of the study to control bias, and the similarity between the study population and the population currently being considered in a clinical setting.

With respect to bacterial vaccination in feedlot cattle, sources regarded as the strongest evidence for the effectiveness of vaccination against Mannheimia haemolytica, Pasteurella multocida and Histophilus somni for mitigating the incidence and effect of bovine respiratory disease (BRD) complex are randomized controlled clinical trials in feedlot cattle under a typical husbandry environment with adequate blinding of investigators, a clear case-definition of BRD, and adequate intensity and length of follow-up; or systematic reviews of more than one trial that meet these criteria. In addition, other available evidence, including: studies testing the effects of 
vaccination of cattle exposed to pathogen-challenged disease models, studies testing the effects of vaccination of cattle in dissimilar production settings (i.e. dairy calves), and studies utilizing in vitro methodologies to test vaccination effects can be used as indirect indicators in the clinical decision-making process, particularly when higher levels of evidence are lacking.

The 'body-of-evidence' for this clinical question is the sum of multiple studies investigating the effect of vaccines against Mannheimia haemolytica, Pasteurella multocida and Histophilus somni administered to cattle. Each individual research study contributes to that body of evidence and each publication can be ranked on a scale from weak evidence to very strong evidence; which for the veterinary practitioner, implies an increasing confidence in recommendations based on a particular study. And, although a simple ranking of experimental trial types is helpful to describe ascending levels of evidence, by its simplistic nature, it incorrectly depicts levels of evidence as a one dimensional and straightforward hierarchy. For example, veterinarians are often confronted with determinations such as, which is better evidence, a randomized trial in three month-old dairy calves (i.e. non-target animals, but a study design with high control of bias and confounding), or a pathogen-challenged disease model study in feedlot cattle (i.e. study with less external validity but in the target population)? In these situations, the clinical expertise, experience, and judgment of the veterinarian must be utilized to aid the ranking of evidence generated by these studies and to guide recommendations for use of bacterial respiratory pathogen vaccines into processing protocols in the field.

Veterinarians considering the strength of evidence must use several perspectives to determine the reliability of research for clinical use.

1) The first consideration is the internal validity of the research, which is determined by the study method and appropriate use of controls for bias. Research reports with good 
internal validity provide assurance that the results represent an unbiased estimate of the true direction and magnitude of the treatment effect in the study population. For randomized controlled studies, accepted methods of random allocation and blinding of study investigators to the treatment for each experimental unit are key experimental design features to avoid bias and confounding.

2) The second consideration is the population used in the research and its appropriateness as a model for the population that generated the clinical question. Generally, the target species in similar housing and husbandry environments provides stronger evidence than the target species in significantly different housing and husbandry environments, related species, unrelated species, or in-vitro methods.

3) And thirdly the clinical relevance of the outcomes of the research should be considered with patient- or herd-oriented outcomes (such as morbidity risk, mortality risk, or average daily weight gain) providing more direct evidence of intervention effectiveness than disease-oriented outcome measurements such as behavior frequency, body temperature, or antibody response.

Using these considerations, the highest rating in all three dimensions would provide the highest level of evidence.

\section{MATERIALS AND METHODS}

A literature search was conducted to identify studies published in English that reported the effectiveness of Mannheimia (Pasteurella) haemolytica, Pasteurella multocida, and Histophilus (Heamophilus) somnus vaccination in cattle. A search strategy using (Mannheimia haemolytica OR Pasteurella haemolytica OR Pasteurella multocida OR Haemophilus somnus 
OR Histophilus somni) AND (respiratory disease OR pneumonia OR pneumonic) AND (bovine OR cattle OR bos) AND (vaccine OR vaccinate) was used to query PubMed (164), CAB abstracts (379) and Biologic Abstracts (160) followed by a hand search through cited references (4). A published manuscript is considered a "study" while a "trial" is a direct comparison of a vaccine treatment to a control treatment within a study. A single study may include more than one trial. After reading the abstract from each unique publication, thirty-four studies were included in this review. Fifteen studies (twenty-two trials) were considered the highest level of evidence in that they were trials utilizing feedlot or stocker cattle in North American production settings appropriately allocated to treatment groups with naturally occurring disease.[8-22] One or more trials from five other studies were identified that utilized feedlot cattle in typical North American production settings, but they were weakened by lack of blinding, treatment being confounded by arrival group or other vaccine treatment, or significant loss-to-follow up and were discarded from the summary.[23-27] In addition, three terminal studies (five trials) investigated the use of commercially available vaccines in feedlot cattle with a pathogen-challenged disease model $[14,28,29]$, three studies (five trials) utilized dairy or beef calves with naturally occurring disease to investigate effects of vaccination [27,30,31], and thirteen studies investigated the use of commercially available vaccines in dairy calves with an induced-disease model.[32-44] Studies were excluded from the review: if they did not report original data (primary study), if they did not include a non-vaccinated/placebo control group, if the outcome did not include an assessment of morbidity risk, mortality risk, or extent of lung involvement (e.g. only reported serologic titers), or if the same results were published in a more complete form elsewhere. Many studies did not report specific allocation schemes used or whether or not effective blinding occurred, and some studies utilized inappropriate statistical tests for the data collected. Studies 
with obvious limitations due to experimental design were excluded, but studies with poorly described experimental designs were retained.

A meta-analysis was done and a Mantel-Haenszel risk ratio (RR) and 95\% confidence interval (95\% CI) were calculated for each trial reporting cumulative incidence of BRD morbidity or mortality (or crude morbidity or mortality).[45] Calculated RR less than 1.0 indicates that vaccinates had lower cumulative incidence compared to controls; while RR greater than 1.0 indicates that vaccinates had higher cumulative incidence compared to controls. In order to be considered to have a statistically significantly lower morbidity or mortality cumulative incidence in vaccinates compared to controls, the upper limit of the $95 \%$ confidence interval must be below 1.0; while in order to consider the cumulative incidence of morbidity or mortality to be statistically significantly higher in vaccinates compared to controls, the lower limit of the 95\% confidence interval must be greater than 1.0. A Forest plot is provided to demonstrate graphically the relative strength of the treatment effects.

\section{RESULTS}

\section{Studies utilizing feedlot cattle with naturally occurring disease (Appendix 1)}

Data was extracted from the fifteen studies (twenty-two trials) that tested the effectiveness of vaccination against one or more of the bacterial pathogens: Mannheimia haemolytica, Pasteurella multocida and Histophilus somni in feedlot cattle for mitigating the incidence and effect of bovine respiratory disease complex using feedlot cattle with naturally occurring disease in order to calculate the risk ratio (RR) for each trial (Appendix 1). Using the criteria outlined in this manuscript, these studies are expected to provide the highest level of evidence from the available studies identified in the literature search. A brief account of the 
studies, including a description of how the cattle were allocated to treatment, the timing of vaccine administration, and a characterization of the vaccines used, can be found in the appendices.

All twenty-two trials reported a cumulative incidence for morbidity. For some trials the case definition for being considered a case was not specified, other studies had clear case definitions for BRD morbidity. Some studies reported crude morbidity and mortality risk (morbidity or mortality due to any cause) while some studies reported BRD-specific morbidity and mortality risk.

\section{$\underline{M}$. haemolytica and M. haemolytica $+P$. multocida vaccines}

Studies investigating the effectiveness of several different commercially available vaccines against $M$. haemolytica (15 trials) and $M$. haemolytica $+P$. multocida (3 trials) were summarized, with three out of eighteen trials reporting a statistically significant reduction in BRD morbidity cumulative incidence in vaccinates compared to controls (e.g. upper 95\% confidence interval was less than 1.00) [10,16,17], while four reported an increased risk of BRD morbidity $[8,17,20]$ and eleven $[9-15,18-20]$ reported a decreased risk of BRD morbidity cumulative incidence that was not different from control populations (Figure 1). The summary RR for these trials is 0.93 with a 95\% confidence interval that does not cross 1.0 (0.89-0.98), indicating a statistically significant lower risk of morbidity in vaccinated feedlot cattle compared to controls.

The fifteen trials that investigated the effect of $M$. haemolytica-only vaccine accounted for $90 \%$ of the weighted summary RR; and two out of fifteen trials reported a statistically significant reduction in BRD morbidity cumulative incidence in vaccinates compared to controls 
$[16,17]$, while three reported an increased risk of BRD morbidity $[17,20]$ and ten $[9-15,18-20]$ reported a decreased risk of BRD morbidity cumulative incidence that was not different from controls. The three trials that investigated the effect of $M$. haemolytica $+P$. multocida vaccination accounted for $10 \%$ of the weighted summary RR. One of the three trials reported a statistically significant reduction in BRD morbidity cumulative incidence in vaccinates compared to controls [23], while one reported an increased risk of BRD morbidity [8] and one [23] reported a decreased risk of BRD morbidity cumulative incidence that was not different from control populations.

Figure 1. Forest plot of risk ratio (RR) for eighteen trials comparing cumulative morbidity incidence of feedlot cattle vaccinated against Mannheimia haemolytica (15 trials) or $M$. haemolytica + Pasteurella multocida (3 trials) compared to controls.

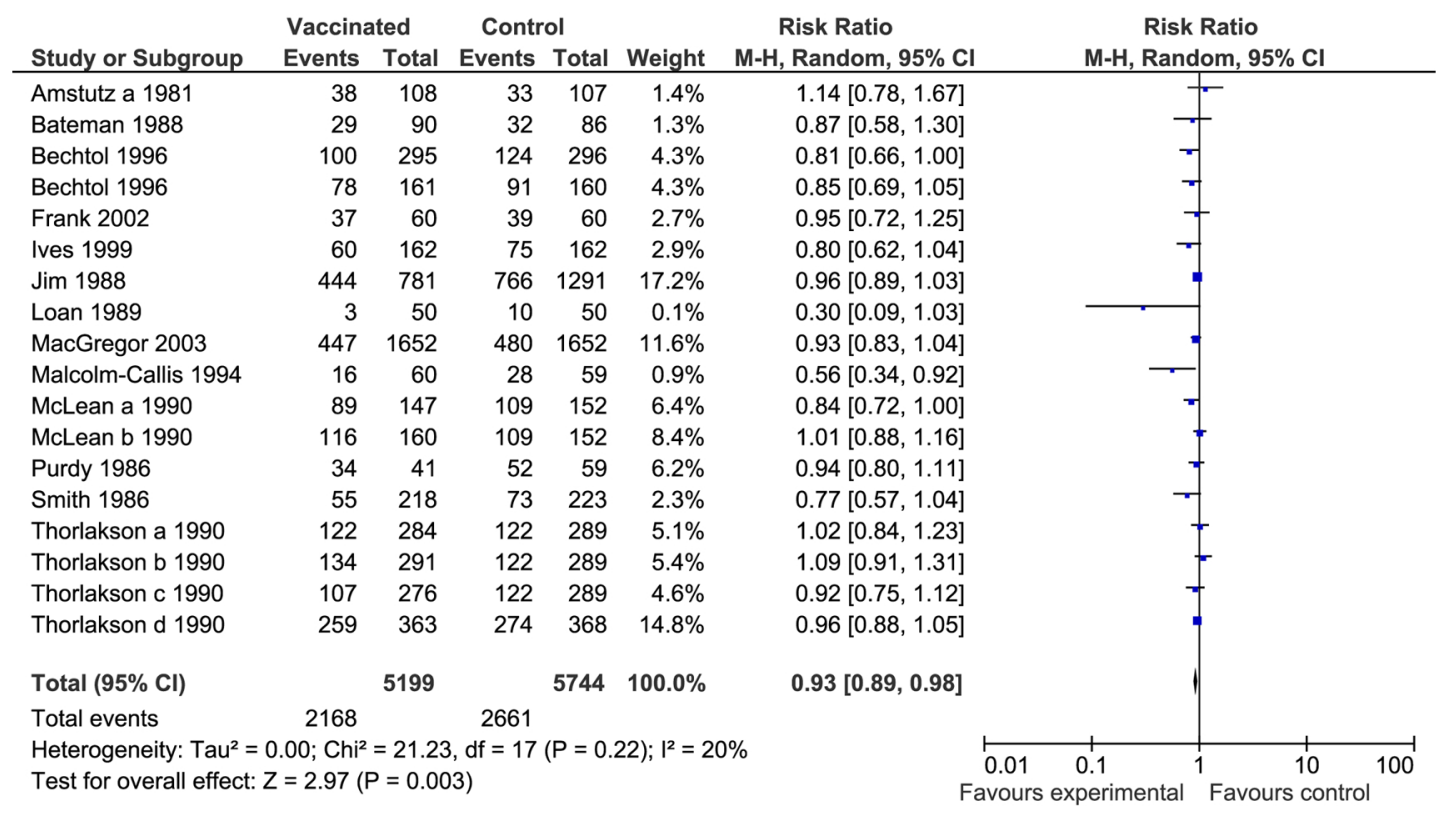

Evaluating mortality RR in nine studies that measured BRD-specific or crude mortality risk indicates that seven trials reported decreased cumulative mortality incidence that was not different in vaccinates relative to controls, while two reported an increased risk of mortality that 
was not different from control populations.[10,12,15-18,20] An additional six trials reported cumulative mortality incidence, but the risk ratio could not be calculated because of non-events (zero for very low count cells) (Figure 2). The summary RR for these trials is 0.76 with a $95 \%$ confidence interval that crosses $1.0(0.56-1.04)$, indicating mortality risk in vaccinated feedlot cattle is not statistically different than controls.

Figure 2. Forest plot of risk ratio (RR) for nine trials comparing cumulative mortality incidence of feedlot cattle vaccinated against Mannheimia haemolytica (7 trials) or M. haemolytica + Pasteurella multocida (2 trials) compared to controls.

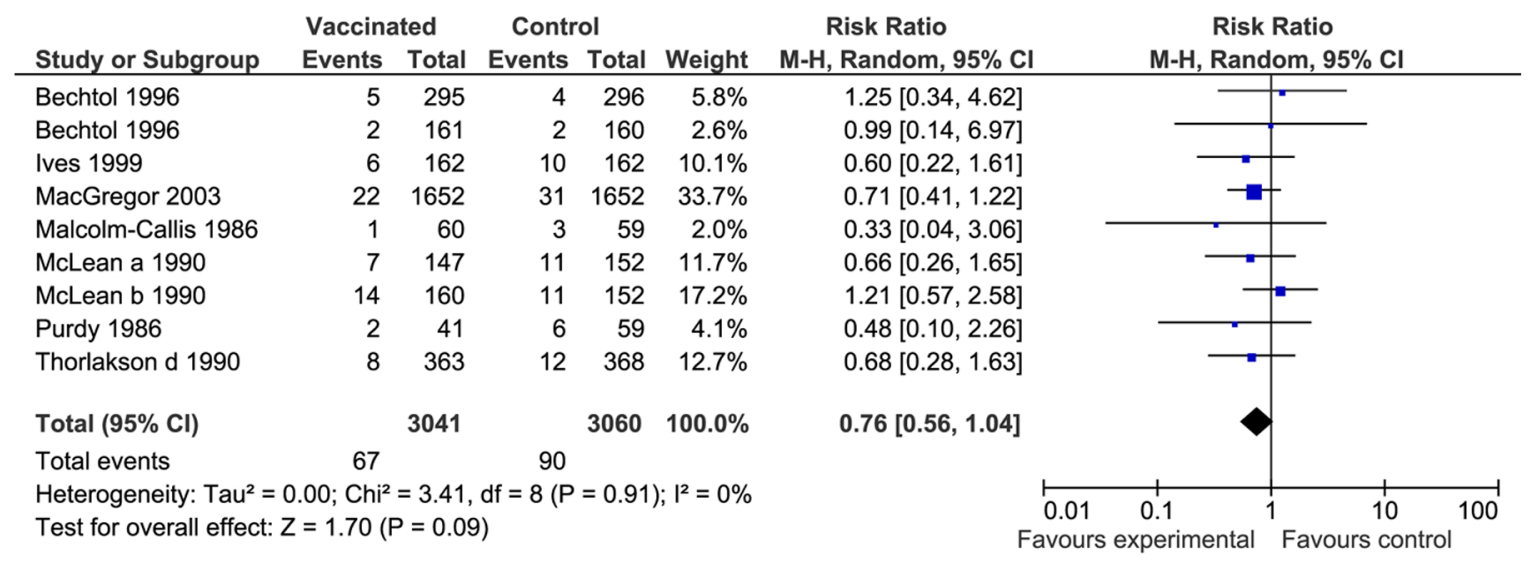

\section{M.. haemolytica $+H$. somni vaccine studies}

One study investigated the effectiveness of a commercially available vaccine against $M$. haemolytica + H. somni in feedlot cattle with natural disease challenge. [21] In this study, vaccinated cattle had statistically significantly lower morbidity compared to controls. There were no deaths in the vaccinates or controls (Appendix 1).

\section{H. somni vaccine studies}

Three trials were identified that investigated the effectiveness of $H$. somni vaccination of feedlot cattle to decrease the cumulative incidence of BRD due to natural challenge.[8,22] The 
summary RR is $0.97(95 \%$ CI $0.61,1.54)$ indicating that BRD morbidity risk of vaccinated cattle was not statistically different than controls (Figure 3).

Figure 3. Forest plot of risk ratio (RR) for three trials comparing cumulative morbidity incidence of feedlot cattle vaccinated against Histophilus somni to controls.

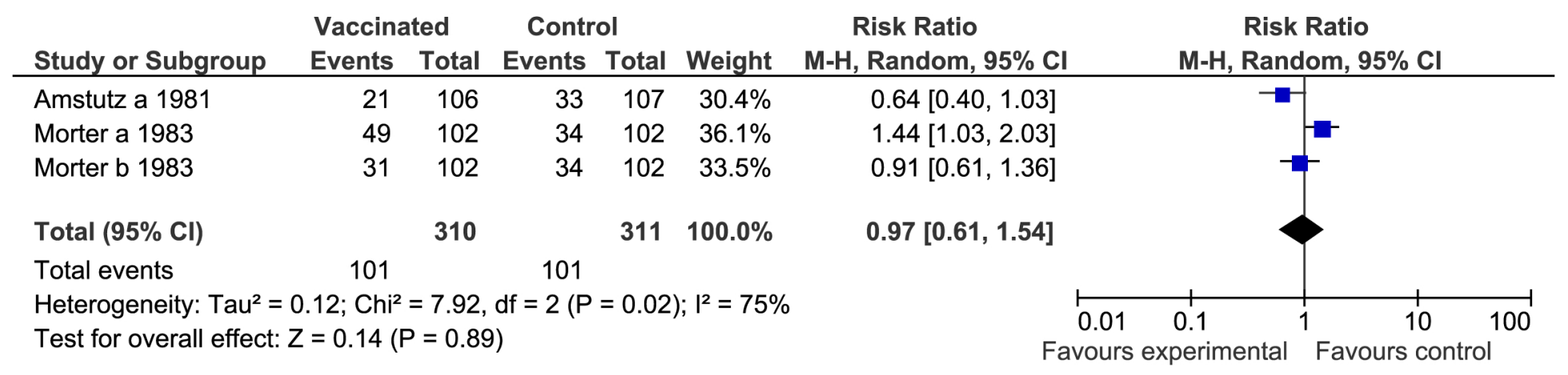

As these studies provide the highest level of evidence for making the clinical decision about the effectiveness of vaccination against the pathogens Mannheimia haemolytica, Pasteurella multocida and Histophilus somni in feedlot cattle for mitigating the incidence and effect of bovine respiratory disease (BRD) complex, the weight of evidence from these twentytwo trials is particularly important. The summary RR indicates that these studies indicate that vaccination against Mannheimia haemolytica or M. haemolytica + Pasteurella multocida has the potential to decrease the incidence of bovine respiratory disease complex in feedlot cattle, but the numerical decrease in mortality risk was not statistically different from controls. Much less evidence is available to determine the effectiveness of vaccination against Histophilus somni in feedlot cattle, and although these studies using natural disease challenge indicate that the risk of BRD does not appear to be affected by vaccination against this pathogen, we have very little power to detect a true difference if it did exist. 
Studies utilizing feedlot cattle with pathogen-challenged disease models (Appendix 2)

\section{M. haemolytica vaccines}

Three studies reporting five trials were identified that utilized feedlot cattle to evaluate the association between vaccination with commercially available $M$. haemolytica vaccines and mortality risk and lung lesion severity following induced disease with a transthoracic inoculation of M. haemolytica.[14,28,29] All five trials reported increased survival post-challenge and the four trials that reported lung severity, indicated decreased percentage of total lung volume being classified as pneumonic in vaccinates compared to controls.

\section{Studies utilizing dairy or beef calves with naturally occurring disease (Appendix 3) \\ M. haemolytica and M. haemolytica + P. multocida vaccines}

Studies utilizing dairy or beef calves during the first three to six months of life to test the efficacy of a vaccine against $M$. haemolytica or a combination vaccine against $M$. haemolytica + P. multocida are not considered to provide a high level of evidence for clinical questions arising from feedlot cattle health problems because of differences in age, housing, and management. Figure 4 depicts the Forest plots of the RR for BRD morbidity for three trials utilizing dairy calves vaccinated against $M$. haemolytica (2 trials) or M. haemolytica + P. multocida (1 trial).[27,30] Figure 5 depicts the Forest plot of the RR for crude mortality for two dairy calf trials evaluating $M$. haemolytica vaccine.[27] The trials that evaluated the effectiveness of $M$. haemolytica or M. haemolytica + P. multocida revealed summary RR indicating a statistically significant reduction in BRD morbidity (Figure 4), but not crude mortality (Figure 5) in vaccinated calves compared to controls. 
Figure 4. Forest plot of risk ratio $(\mathrm{RR})$ for three trials comparing cumulative morbidity incidence of dairy calves vaccinated against Mannheimia haemolytica or M. haemolytica + Pasteurella multocida compared to controls.

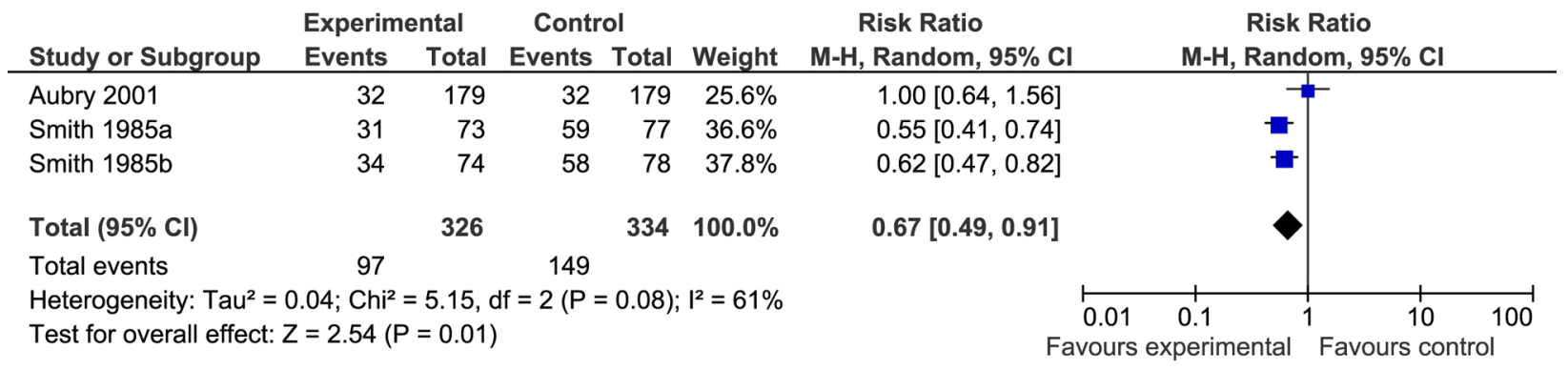

Figure 5. Forest plot of risk ratio (RR) for two trials comparing cumulative mortality incidence of dairy calves vaccinated against Mannheimia haemolytica compared to controls.

\begin{tabular}{|c|c|c|c|c|c|c|c|c|c|c|}
\hline Study or Subgroup & \multicolumn{2}{|c|}{ Experimental } & \multicolumn{2}{|c|}{ Control } & Weight & \multicolumn{2}{|l|}{ Risk Ratio } & \multicolumn{2}{|c|}{$\begin{array}{c}\text { Risk Ratio } \\
\text { M-H, Random, } 95 \% \mathrm{Cl} \\
\end{array}$} & \\
\hline Smith 1985a & 2 & 74 & 10 & 78 & $43.2 \%$ & $0.21[0.05,0.93]$ & & & & \\
\hline Smith $1985 b$ & 6 & 179 & 7 & 179 & $56.8 \%$ & $0.86[0.29,2.50]$ & & & & \\
\hline Total $(95 \% \mathrm{Cl})$ & & 253 & & 257 & $100.0 \%$ & $0.47[0.12,1.85]$ & & & & \\
\hline Total events & 8 & & 17 & & & & & & & \\
\hline $\begin{array}{l}\text { Heterogeneity: } \mathrm{Tau}^{2}= \\
\text { Test for overall effect: }\end{array}$ & $\begin{array}{l}.57 ; \mathrm{Chi}^{2} \\
=1.08(\mathrm{~F}\end{array}$ & $\begin{aligned} & 2.30, c \\
= & 0.28)\end{aligned}$ & $f=1(P=$ & $=0.13)$ & $1^{2}=57 \%$ & & $\begin{array}{l}0.01 \\
\text { vours }\end{array}$ & $\begin{array}{l}0.1 \\
\text { xperimental }\end{array}$ & $\begin{array}{lc}1 & 10 \\
\text { Favours cont }\end{array}$ & $\underset{\text { ol }}{100}$ \\
\hline
\end{tabular}

\section{M. haemolytica + H. somni vaccine studies}

Calves vaccinated with a genetically attenuated leukotoxin of $M$. haemolytica combined with bacterial extracts of $M$. haemolytica and $H$. somni did not have statistically significantly different risk of BRD morbidity compared to controls (Figure 6).[31] 
Figure 6. Forest plot of risk ratio (RR) for two trials comparing cumulative morbidity incidence of dairy calves vaccinated against Mannheimia haemolytica + Histophilus somni compared to controls.

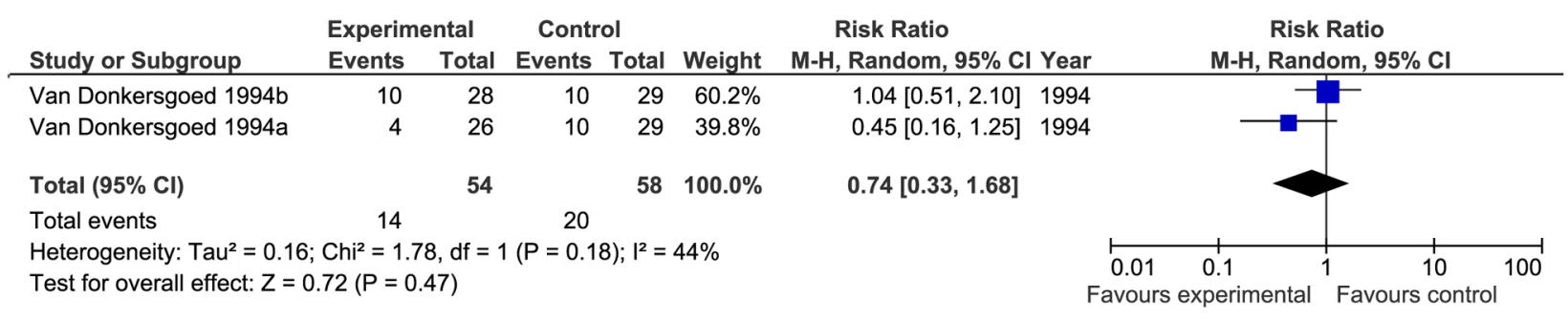

\section{DISCUSSION}

The clinical question of whether or not to utilize commercially available vaccines against bacterial pathogens associated with BRD in feedlot cattle is important to the veterinarians and producers making the decision, as well as to the health and well-being of feedlot cattle. Making an evidence-based clinical decision based primarily on published, scientifically accepted controlled trials utilizing feedlot cattle, with supportive information from published trials utilizing pathogen-challenged disease models or using dairy or beef calves housed and managed under different husbandry systems, requires not only the gathering and summarizing of the available information, but also considering the context of specific clinical questions. The summary data would indicate potential benefit for vaccination of feedlot cattle against Mannheimia haemolytica and Pasteurella multocida with no evidence of benefit for vaccination against Histophilus somni for mitigating the incidence and effect of bovine respiratory disease complex. Unfortunately, the published body of evidence does not provide a consistent estimate of the direction and magnitude of effectiveness in feedlot cattle vaccination against Mannheimia haemolytica, Pasteurella multocida, or Histophilus somni. 
One limitation for the conclusions that can be drawn from this group of studies includes the fact that all the feedlot studies with natural disease challenge mixed vaccinated and unvaccinated calves in the same feedlot pens. This mixing may under-estimate the value of vaccination because of the phenomena of herd-immunity. In mixed pens, the vaccinated calves may reduce the disease challenge for unvaccinated controls and unvaccinated calves may increase the disease challenge for vaccinated calves compared to the exposure expected when entire pens are either vaccinated or not vaccinated. Another limitation is that some studies reported crude morbidity and mortality while other studies reported BRD-specific morbidity and mortality. Approximately 59\% of the weighted summary RR for morbidity in the feedlot studies was derived from studies using a case definition for BRD as the criteria for being classified as a morbid animal, while $41 \%$ of the weighted summary RR came from studies reporting the effect of vaccination in all causes of morbidity. Similarly, approximately $57 \%$ of the weighted summary RR for mortality in the feedlot studies came from studies specifying mortalities associated with BRD, while $43 \%$ of the weighted summary RR was derived from studies reporting the effect of vaccination on all causes of mortality. If non-BRD mortalities were evenly distributed between vaccinates and controls in these studies, aggregating mortality of all causes to test the association with vaccination status will decrease the risk ratio between vaccinates and non-vaccinated controls.

A thorough search of the published literature and a structured meta-analysis to produce a summary Mantel-Haenszel risk ratio (RR) and 95\% confidence interval (95\% CI) are helpful tools for making an assessment of the evidence for the effectiveness of vaccination against Mannheimia haemolytica, Pasteurella multocida and Histophilus somni for mitigating the incidence and effect of bovine respiratory disease (BRD) complex in feedlot cattle. However, 
because of the limitations of the studies used in the meta-analysis and the various specific clinical situations that feedlot veterinarians and producers confront, it is necessary to combine this summary with other sources of information and unpublished data, as well as continued monitoring of recommendations to arrive at the best advice for feedlot clients.

\section{REFERENCES}

1. Evidence-Based Medicine Working Group. Evidence-based medicine: a new approach to teaching the practice of medicine, J Am Med Assoc 1992;268:2420-2425.

2. Keene BW. Towards evidence-based veterinary medicine (editorial), J Vet Intern Med 2000;14:118-119.

3. Doig GS. Evidence-based veterinary medicine: what it is, what it isn't and how to do it, Aust Vet J 2003;81:412-415.

4. Roudebush P, Allen TA, Dodd CE, et al. Evidence-based Medicine: Applications to veterinary clinical nutrition, J Am Vet Med Assoc 2004;224:1766-1771.

5. Sackett DL. Rules of evidence and clinical recommendations, Can J Cardiol 1993;9:487489.

6. Dans AL, Dans LF, Guyatt GH, et al. Users' guide to the medical literature. XIV. How to decide on the applicability of clinical trial results to your patient, J Am Med Assoc 1998;279:545-549.

7. Berg AO, Dimensions of evidence. In: Geyman JP, Deyo RA, Ramsey SD, editors: Evidence-based clinical practice: concepts and approaches, Boston, 2000, ButerworthHeinemann. 
8. Amstutz H E, Horstman LA, Morter RL. Clinical evaluation of the efficacy of Haemophilus somnus and Pasteurella sp. bacterins. Bov Pract 1981;16:106-108.

9. Bateman KG. Efficacy of a Pasteurella haemolytica vaccine/bacterial extract in the prevention of bovine respiratory disease in recently shipped feedlot calves. Can Vet J 1988;29:838-9.

10. Bechtol DT, Jones GF. Can a Pasteurella vaccine prevent respiratory disease in calves in a backgrounding lot? Vet Med 1996;91:1042-1045.

11. Frank GH, Briggs RE, Duff GC, et al. Effects of vaccination prior to transit and administration of florfenicol at time of arrival in a feedlot on the health of transported calves and detection of Mannheimia haemolytica in nasal secretions. Am J Vet Res 2002;63:251-6.

12. Ives S, Drouillard J, Anderson D, et al. Comparison of morbidity and performance among stressed feeder calves following vaccination with PYRAMID MLV 4 or PYRAMID $4+$ PRESPONSE SQ. Kansas State University, Cattlemen’s Day, Report of Progress 1999;831:126-0129.

13. Jim K, Guichon T, Shaw G. Protecting feedlot calves from pneumonic pasteurellosis. Vet Med 1988;83:1084-1087.

14. Loan RW, Tigges MG, Purdy CW. A tissue culture-derived Pasteurella haemolytica vaccine. Bov Pract 1989;24:22-24.

15. MacGregor S, Smith D, Perino LJ, et al. An evaluation of the effectiveness of a commercial Mannheimia (Pasteurella) haemolytica vaccine in a commercial feedlot. Bov Pract 2003; 37:78-82. 
16. Malcolm-Callis KJ, Galyean ML, Duff GC. Effects of dietary supplemental protein source and a Pasteurella haemolytica toxoid on performance and health of newly received calves. Agri Pract 1994;15:22-28.

17. McLean GS, Smith RA, Gill RA, et al. An evaluation of an inactivated, leukotoxin-rich, cell-free Pasteurella haemolytica vaccine for prevention of undifferentiated bovine respiratory disease. Ok State Univ An Sci Res Rep MP-129 1990:135-140.

18. Purdy CW, Livingston CW, Frank GH, et al. A live Pasteurella haemolytica vaccine efficacy trial. J Am Vet Med Assoc 1986;188: 589-591.

19. Smith RA, Gill DR, Hicks RB. Improving the performance of stocker and feedlot calves with a live Pasteurella haemolytica vaccine. Vet Med 1986;81:978-981.

20. Thorlakson B, Martin W, Peters D. A field trial to evaluate the efficacy of a commercial Pasteurella haemolytica bacterial extract in preventing bovine respiratory disease. Can Vet J 1990;31:573-9.

21. Van Donkersgoed J, Schumann FJ, Harland RJ, et al. The effect of route and dosage of immunization on the serological response to a Pasteurella haemolytica and Haemophilus somnus vaccine in feedlot calves. Can Vet J 1993;34:731-735.

22. Morter RL, Amstutz HE. Evaluating the efficacy of a Haemophilus somnus bacterin in a controlled field trial. Bov Pract 1983;18:82-83.

23. Bechtol DT, Ballinger RT, Sharp AJ. Field trial of a Pasteurella haemolytica toxoid administered at spring branding and in the feedlot. Agri-Practice 1991;12:6-14 .

24. Bennett BW. Efficacy of Pasteurella bacterins for yearling feedlot cattle. Bov Pract 1982;3: 26-30. 
25. Martin, W., Acres, S., Janzen, E., et al. A field trial of preshipment vaccination of calves. Can Vet J 1984; 25:145-147.

26. Ribble CS, Jim GK, Janzen ED. Efficacy of immunization of feedlot calves with a commercial Haemophilus somnus bacterin. Can J Vet Res 1988;52:191-8.

27. Smith CK, Davidson JN, Henry CW Jr. Evaluating a live vaccine for Pasteurella haemolytica in dairy calves. Vet Med 1985;80:78-88.

28. Confer AW, Fulton RW. Evaluation of Pasteurella and Haemophilus vaccines. Proceed of the 27th Conv AABP 1995;136-141.

29. Confer AW, Ayalew S, Panciera RJ, et al. Immunogenicity of recombinant Mannheimia haemolytica serotype 1 outer membrane protein PlpE and augmentation of a commercial vaccine. Vaccine 2003;21/22: 2821-2829.

30. Aubry P, Warnick LD, Guard CL, et al. Health and performance of young dairy calves vaccinated with a modified-live Mannheimia haemolytica and Pasteurella multocida vaccine. J Am Vet Med Assoc 2001; 219: 1739-1742.

31. Van Donkersgoed J, Potter AA, Mollison B, Harland RJ. The effect of a combined Pasteurella haemolytica and Haemophilus somnus vaccine and a modified-live bovine respiratory syncytial virus vaccine against enzootic pneumonia in young beef calves. Can Vet J 1994;35:239-41.

32. Blanchard-Channell MT, Ashfaq MK, Kadel WL. Efficacy of streptomycin-dependent, live Pasteurella haemolytica vaccine against challenge exposure to Pasteurella haemolytica in cattle. Am J Vet Res 1987;48:637-642. 
33. Cardella MA, Adviento MA, Nervig RM. Vaccination studies against experimental bovine Pasteurella pneumonia. Can J Vet Res 1987;51: 204-211.

34. Catt DM, Chengappa MM, Kadel WL, et al. Preliminary studies with a live streptomycindependent Pasteurella multocida and Pasteurella haemolytica vaccine for the prevention of bovine pneumonic pasteurellosis. Can J Comp Med 1985;49:366-371.

35. Chengappa MM, McLaughlin BG, Craft DL. Bovine pneumonic pasteurellosis: efficacy testing a live vaccine. Vet Med 1998;83:837-840.

36. Conlon JAR, Gallo GF, Shewen PE, et al. Comparison of protection of experimentally challenged cattle vaccinated once or twice with a Pasteurella haemolytica bacterial extract vaccine. Can J Vet Res 1995;59:179-182.

37. DeBey BM, Roth JA, Brogden KA, et al. In vitro lymphocyte proliferative responses and gamma-interferon production as measures of cell-mediated immunity of cattle exposed to Pasteurella haemolytica. Can J Vet Res 1996;60:263-70.

38. Shewen PE, Wilkie BN. Vaccination of calves with leukotoxic culture supernatant from Pasteurella haemolytica. Can J Vet Res. 1988;52:30-6.

39. Shewen PE, Lee CW, Perets A, et al. Efficacy of recombinant sialoglycoprotease in protection of cattle against pneumonic challenge with Mannheimia (Pasteurella) haemolytica A1. Vaccine 2003;21:1901-1906.

40. Shewen PE, Sharp A, Wilkie BN. Efficacy testing a Pasteurella haemolytica extract vaccine. Vet Med 1988;83:1078-1083. 
41. Srinand S, Mahewsaran SK, Amees TR, et al. Evaluation of efficacy of three commercial vaccines against experimental bovine pneumonic pasteurellosis. Vet Micro 1996;52:8189.

42. Berghaus LJ, Corbeil LB, Berghaus RD, et al. Effects of dual vaccination for bovine respiratory syncytial virus and Haemophilus somnus on immune responses. Vaccine 2006;24:6018-6027.

43. Cairns R, Chu HJ, Chavez LG, Schnackel JA. Efficacy of an outer membrane complex Haemophilus somnus bacterin in preventing symptoms following Haemophilus somnus challenge. Agri-Practice 1993;14:35-37.

44. Groom SC, Little PB. Effects of vaccination of calves against induced Haemophilus somnus pneumonia. Am J Vet Res 1988;49:793-800.

45. Review Manager (RevMan), Version 5.1 Copenhagen: The Nordic Cochrane Centre, The Cochrane Collaboration, 2011. 
Appendix 1. Articles reviewed for the evaluation of effectiveness of commercially available vaccines against Mannheimia haemolytica, Pasteurella multocida and/or Histophilus somni in feedlot cattle using natural disease challenge with cumulative morbidity risk and/or cumulative mortality risk reported as an outcome

\begin{tabular}{|c|c|c|c|}
\hline Reference & Study Description & Vaccine & Risk Ratio (95\% CI) \\
\hline \multicolumn{4}{|c|}{ Mannheimia. haemolytica and M. haemolytica + Pasteurella multocida vaccine studies } \\
\hline $\begin{array}{l}\text { Amstutz et al. } \\
\text { Bov Pract } 1981\end{array}$ & $\begin{array}{l}\text { Random allocation of beef } \\
\text { heifers vaccinated at } \\
\text { feedlot arrival and } 21 \text { days } \\
\text { later }\end{array}$ & $\begin{array}{l}\text { M. haemolytica }+P \\
\text { multocida bacterin / } 2 \\
\text { IM doses }\end{array}$ & $\begin{array}{l}\text { BRD Morbidity: RR=1.14 (0.78-1.67) } \\
\text { Tx: } 38 / 108 \\
\text { Control: } 33 / 107 \\
\text { BRD Mortality: RR=not calculated } \\
\text { Tx: } 1 / 108 \\
\text { Control: } 2 / 107\end{array}$ \\
\hline $\begin{array}{l}\text { Bateman. Can } \\
\text { Vet J } 1988\end{array}$ & $\begin{array}{l}\text { Randomized control trial } \\
\text { allocation using beef } \\
\text { calves (avg. 255-268 kg) } \\
\text { housed at two different } \\
\text { locations vaccinated at } \\
\text { feedlot arrival }\end{array}$ & $\begin{array}{l}\text { Inactivated } M \text {. } \\
\text { haemolytica, bacteria- } \\
\text { free extract with } \\
\text { leukotoxoid and } \\
\text { bacterial surface } \\
\text { subunit antigens /1 IM } \\
\text { dose }\end{array}$ & $\begin{array}{l}\text { BRD Morbidity: RR=0.89 (0.58-1.30) } \\
\text { Tx: } 29 / 90 \\
\text { Control: } 32 / 86 \\
\text { Crude Mortality: RR=not calculated } \\
\text { Tx: } 0 / 90 \\
\text { Control: } 0 / 86\end{array}$ \\
\hline $\begin{array}{l}\text { Bechtol and } \\
\text { Jones. Vet Med } \\
1996\end{array}$ & $\begin{array}{l}\text { Randomized block (paired } \\
\text { sequentially by processing } \\
\text { order) allocation using beef } \\
\text { heifers }(160-170 \mathrm{~kg} \text { ) } \\
\text { vaccinated at spring arrival } \\
\text { to } 45 \text {-day backgrounding } \\
\text { lot }\end{array}$ & $\begin{array}{l}\text { Avirulent live culture of } \\
M \text {. haemolytica and } P \text {. } \\
\text { multocida/1 IM dose }\end{array}$ & $\begin{array}{l}\text { Crude Morbidity: RR=0.81 (0.66-1.00) } \\
\text { Tx: } 100 / 295 \\
\text { Control: } 124 / 296 \\
\text { Crude Mortality: RR=1.25 (0.34-4.62) } \\
\text { Tx: } 5 / 295 \\
\text { Control: } 4 / 296 \\
\text { (some pens were mass medicated) }\end{array}$ \\
\hline $\begin{array}{l}\text { Bechtol and } \\
\text { Jones. Vet Med } \\
1996\end{array}$ & $\begin{array}{l}\text { Randomized block (paired } \\
\text { sequentially by processing } \\
\text { order) allocation using beef } \\
\text { heifers (160-170 kg) } \\
\text { vaccinated at July arrival to } \\
\text { 45-day backgrounding lot }\end{array}$ & $\begin{array}{l}\text { Avirulent live culture of } \\
M \text {. haemolytica and } P \text {. } \\
\text { multocida/1 IM dose }\end{array}$ & $\begin{array}{l}\text { Crude Morbidity: RR=0.85(0.69-1.05) } \\
\text { Tx: } 78 / 161 \\
\text { Control: } 91 / 160 \\
\text { Crude Mortality: RR= } \mathbf{0 . 9 9}(\mathbf{0 . 1 4 - 6 . 9 7 )} \\
\text { Tx: } 2 / 161 \\
\text { Control: } 2 / 160 \\
\text { (some pens were mass medicated }\end{array}$ \\
\hline $\begin{array}{l}\text { Frank et al. } \\
\text { AJVR } 2002\end{array}$ & $\begin{array}{l}\text { Systematic (every-other- } \\
\text { steer) allocation using 170- } \\
230 \text { kg steers vaccinated at } \\
\text { order buyer premises prior } \\
\text { to transit to a feedlot }\end{array}$ & $\begin{array}{l}\text { Bacterin-Toxoid } \\
\text { (chemically inactivated } \\
\text { culture of multiple } \\
\text { isolate of } M \text {. } \\
\text { haemolytica)/ } 1 \mathrm{IM} \\
\text { dose }\end{array}$ & $\begin{array}{l}\text { BRD Morbidity: RR=0.95 (0.72-1.25) } \\
\text { Tx: } 37 / 60 \\
\text { Control: } 39 / 60\end{array}$ \\
\hline
\end{tabular}




\begin{tabular}{|c|c|c|c|}
\hline $\begin{array}{l}\text { Ives et al. KSU } \\
\text { Cattlemen’s } \\
\text { Day } 1999\end{array}$ & $\begin{array}{l}\text { Systematic (every-other- } \\
\text { heifer) allocation using } \\
\text { beef heifers (avg. } 227 \mathrm{~kg} \text { ) } \\
\text { vaccinated at feedlot } \\
\text { arrival }\end{array}$ & $\begin{array}{l}\text { Inactivated } M \text {. } \\
\text { haemolytica, bacteria- } \\
\text { free extract with } \\
\text { leukotoxoid and } \\
\text { bacterial surface } \\
\text { subunit antigens /1 IM } \\
\text { dose }\end{array}$ & $\begin{array}{l}\text { BRD Morbidity: RR=0.80 (0.62-1.04) } \\
\text { Tx: } 60 / 162 \\
\text { Control: } 75 / 162 \\
\text { BRD Mortality + Chronics } \\
\text { RR=0.60 (0.22-1.61) } \\
\text { Tx: } 6 / 162 \\
\text { Control: } 10 / 162\end{array}$ \\
\hline $\begin{array}{l}\text { Jim et al. Vet } \\
\text { Med } 1988\end{array}$ & $\begin{array}{l}\text { Systematic allocation using } \\
\text { cattle vaccinated at feedlot } \\
\text { arrival and again } 1 \text { to } 5 \\
\text { days later }\end{array}$ & $\begin{array}{l}\text { Inactivated } M \text {. } \\
\text { haemolytica, bacteria- } \\
\text { free extract with } \\
\text { leukotoxoid and } \\
\text { bacterial surface } \\
\text { subunit antigens /2 IM } \\
\text { doses }\end{array}$ & $\begin{array}{l}\text { BRD Morbidity: RR=0.95 (0.89-1.03) } \\
\text { Tx: 444/781 } \\
\text { Control: 766/1291 }\end{array}$ \\
\hline $\begin{array}{l}\text { Loan et al. Bov } \\
\text { Pract } 1989\end{array}$ & $\begin{array}{l}\text { Unknown allocation of } \\
\text { cattle vaccinated at feedlot } \\
\text { arrival and } 28 \text { days prior }\end{array}$ & $\begin{array}{l}\text { Bacterin (tissue culture- } \\
\text { derived } M \text {. haemolytica } \\
\text { bacterin)/ } 2 \text { IM doses }\end{array}$ & $\begin{array}{l}\text { BRD Morbidity: RR=0.30 (0.09-1.03) } \\
\text { Tx: } 3 / 50 \\
\text { Control: } 10 / / 50\end{array}$ \\
\hline $\begin{array}{l}\text { MacGregor et } \\
\text { al. Bov Pract } \\
2003\end{array}$ & $\begin{array}{l}\text { Systematic (every-other- } \\
\text { one) allocation using cattle } \\
\text { vaccinated at feedlot } \\
\text { arrival }\end{array}$ & $\begin{array}{l}\text { Bacterin-toxoid } \\
\text { (chemically inactivated } \\
\text { culture of multiple } \\
\text { isolate of } M \text {. } \\
\text { haemolytica) } 1 \text { dose }\end{array}$ & $\begin{array}{l}\text { BRD Morbidity: RR=0.93 (0.83-1.04) } \\
\text { Tx: } 447 / 1652 \\
\text { Control: 480/1652 } \\
\text { Crude Mortality: } \mathbf{R R = 0 . 6 9 ~ ( 0 . 4 4 - 1 . 0 6 )} \\
\text { Tx: } 33 / 1652 \\
\text { Control: } 48 / 1652 \\
\text { BRD Mortality: } \mathbf{R R}=\mathbf{0 . 7 1}(\mathbf{0 . 4 1 - 1 . 2 2 )} \\
\text { Tx: } 22 / 1652 \\
\text { Control: } 31 / 1652\end{array}$ \\
\hline $\begin{array}{l}\text { Malcolm-Callis } \\
\text { et al. Agri- } \\
\text { Practice } 1986\end{array}$ & $\begin{array}{l}\text { Unknown allocation of } \\
\text { cattle vaccinated at feedlot } \\
\text { arrival and } 14 \text { day later }\end{array}$ & $\begin{array}{l}\text { Inactivated } M \text {. } \\
\text { haemolytica, bacteria- } \\
\text { free extract with } \\
\text { leukotoxoid and } \\
\text { bacterial surface } \\
\text { subunit antigens /2 IM } \\
\text { doses }\end{array}$ & 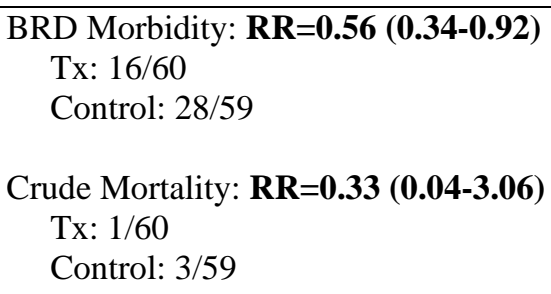 \\
\hline $\begin{array}{l}\text { McLean et al. } \\
\text { Oklahoma State } \\
\text { Univ Animal } \\
\text { Science } \\
\text { Research Report } \\
1990\end{array}$ & $\begin{array}{l}\text { Random allocation of } \\
\text { cattle vaccinated prior to } \\
\text { transit to a feedlot and } 7 \\
\text { days later }\end{array}$ & $\begin{array}{l}\text { Inactivated } M \text {. } \\
\text { haemolytica, bacteria- } \\
\text { free extract with } \\
\text { leukotoxoid and } \\
\text { bacterial surface } \\
\text { subunit antigens /2 IM } \\
\text { doses } \\
\end{array}$ & $\begin{array}{l}\text { BRD Morbidity: RR=0.84 (0.72-1.00) } \\
\text { Tx: } 89 / 147 \\
\text { Control: } 109 / 152 \\
\text { Crude Mortality: } \mathbf{R R}=\mathbf{0 . 6 6}(\mathbf{0 . 2 6 - 1 . 6 5 )} \\
\quad \text { Tx: } 7 / 147 \\
\quad \text { Control: } 11 / 152\end{array}$ \\
\hline $\begin{array}{l}\text { McLean et al. } \\
\text { Oklahoma State } \\
\text { Univ Animal } \\
\text { Science } \\
\text { Research Report } \\
1990\end{array}$ & $\begin{array}{l}\text { Random allocation of } \\
\text { cattle vaccinated at feedlot } \\
\text { arrival and } 7 \text { days later }\end{array}$ & $\begin{array}{l}\text { Inactivated } M \text {. } \\
\text { haemolytica, bacteria- } \\
\text { free extract with } \\
\text { leukotoxoid and } \\
\text { bacterial surface } \\
\text { subunit antigens /2 IM } \\
\text { doses } \\
\end{array}$ & $\begin{array}{l}\text { BRD Morbidity: RR=1.01 (0.88-1.16) } \\
\text { Tx: } 116 / 160 \\
\text { Control: } 109 / 152 \\
\\
\text { Crude Mortality: } \mathbf{R R}=\mathbf{1 . 2 1}(\mathbf{0 . 5 7 - 2 . 5 8 )} \\
\quad \text { Tx: } 14 / 160 \\
\text { Control: } 11 / 152\end{array}$ \\
\hline
\end{tabular}




\begin{tabular}{|c|c|c|c|}
\hline $\begin{array}{l}\text { Purdy et al. } \\
\text { JAVMA } 1986\end{array}$ & $\begin{array}{l}\text { Unknown allocation of } \\
\text { calves from a single ranch } \\
\text { vaccinated } 14 \text { days prior to } \\
\text { transit to an order-buyer } \\
\text { where they remained for } 6 \\
\text { days in contact with other } \\
\text { cattle before being } \\
\text { transported to a feedlot }\end{array}$ & $\begin{array}{l}\text { Live culture of } M \text {. } \\
\text { haemolytica /1 ID dose }\end{array}$ & $\begin{array}{l}\text { BRD Morbidity: RR=0.94 (0.80-1.11) } \\
\text { Tx: } 34 / 41 \\
\text { Control: } 52 / 59 \\
\text { Crude Mortality: RR=0.48 (0.10-2.26) } \\
\text { Tx: } 2 / 41 \\
\text { Control: } 6 / 59\end{array}$ \\
\hline $\begin{array}{l}\text { Smith et al. Vet } \\
\text { Med } 1986\end{array}$ & $\begin{array}{l}\text { Random allocation of } \\
\text { steers and bulls vaccinated } \\
\text { at feedlot arrival }\end{array}$ & $\begin{array}{l}\text { Live culture of } M \text {. } \\
\text { haemolytica /1 ID dose }\end{array}$ & $\begin{array}{l}\text { Crude Morbidity: RR=0.77 (0.57-1.04) } \\
\text { Tx: } 55 / 218 \\
\text { Control: } 73 / 223 \\
\text { Crude Mortality: RR=not calculated } \\
\text { Tx: } 0 / 218 \\
\text { Control: } 1 / 223\end{array}$ \\
\hline $\begin{array}{l}\text { Thorlakson et } \\
\text { al. Can Vet J } \\
1990\end{array}$ & $\begin{array}{l}\text { Systematic allocation of } \\
\text { six to eight month old } \\
\text { cattle vaccinated } 21 \text { days } \\
\text { prior to transit at ranch of } \\
\text { origin (not vaccinated at } \\
\text { feedlot) }\end{array}$ & $\begin{array}{l}\text { Inactivated } M \text {. } \\
\text { haemolytica, bacteria- } \\
\text { free extract with } \\
\text { leukotoxoid and } \\
\text { bacterial surface } \\
\text { subunit antigens/1 IM } \\
\text { dose }\end{array}$ & $\begin{array}{l}\text { Crude Morbidity: RR=1.02 (0.84-1.23) } \\
\text { Tx: } 122 / 284 \\
\text { Control: } 122 / 289 \\
\text { BRD Mortality: RR= not calculated } \\
\text { Tx: } 5 / 284 \\
\text { Control: } 1 / 289\end{array}$ \\
\hline $\begin{array}{l}\text { Thorlakson et } \\
\text { al. Can Vet J } \\
1990\end{array}$ & $\begin{array}{l}\text { Systematic allocation of } \\
\text { six to eight month old } \\
\text { ranch-fresh cattle } \\
\text { vaccinated at feedlot } \\
\text { arrival }\end{array}$ & $\begin{array}{l}\text { Inactivated } M \text {. } \\
\text { haemolytica, bacteria- } \\
\text { free extract with } \\
\text { leukotoxoid and } \\
\text { bacterial surface } \\
\text { subunit antigens /1 IM } \\
\text { dose } \\
\end{array}$ & $\begin{array}{l}\text { Crude Morbidity: RR=1.09 (0.91-1.31) } \\
\text { Tx: } 134 / 291 \\
\text { Control: } 122 / 289 \\
\text { BRD Mortality: RR= not calculated } \\
\text { Tx: } 0 / 291 \\
\text { Control: } 1 / 289 \\
\end{array}$ \\
\hline $\begin{array}{l}\text { Thorlakson et } \\
\text { al. Can Vet J } \\
1990\end{array}$ & $\begin{array}{l}\text { Systematic allocation of } \\
\text { six to eight month old } \\
\text { cattle vaccinated at ranch } \\
\text { of origin } 21 \text { days prior to } \\
\text { transit and at feedlot arrival }\end{array}$ & $\begin{array}{l}\text { Inactivated } M \text {. } \\
\text { haemolytica, bacteria- } \\
\text { free extract with } \\
\text { leukotoxoid and } \\
\text { bacterial surface } \\
\text { subunit antigens /2 IM } \\
\text { doses (arrival and } 21 \text { d } \\
\text { prior) }\end{array}$ & $\begin{array}{l}\text { Crude Morbidity: RR=0.92 (0.75-1.12) } \\
\text { Tx: } 107 / 276 \\
\text { Control: } 122 / 289 \\
\text { BRD Mortality: } \mathbf{R R}=\mathbf{n o t} \text { calculated } \\
\text { Tx: } 2 / 276 \\
\text { Control: } 1 / 289\end{array}$ \\
\hline $\begin{array}{l}\text { Thorlakson et } \\
\text { al. Can Vet J } \\
1990\end{array}$ & $\begin{array}{l}\text { Systematic allocation of } \\
\text { auction derived cattle } \\
\text { vaccinated at feedlot } \\
\text { arrival }\end{array}$ & $\begin{array}{l}\text { Inactivated } M \text {. } \\
\text { haemolytica, bacteria- } \\
\text { free extract with } \\
\text { leukotoxoid and } \\
\text { bacterial surface } \\
\text { subunit antigens /1 IM } \\
\text { dose }\end{array}$ & $\begin{array}{l}\text { Crude Morbidity: RR=0.96 (0.88-1.05) } \\
\text { Tx: } 259 / 363 \\
\text { Control: } 274 / 368 \\
\text { BRD Mortality: } \mathbf{R R = 0 . 6 8}(\mathbf{0 . 2 8}-\mathbf{1 . 6 3}) \\
\text { Tx: } 8 / 363 \\
\text { Control: } 12 / 368\end{array}$ \\
\hline \multicolumn{4}{|c|}{ Mannheimia. haemolytica + Histophilus somni vaccine studies } \\
\hline $\begin{array}{l}\text { Van } \\
\text { Donkersgoed et } \\
\text { al. Can Vet J } \\
1993\end{array}$ & $\begin{array}{l}\text { Random allocation of } \\
\text { steers (avg. } 237 \mathrm{~kg} \text { ) } \\
\text { vaccinated at feedlot } \\
\text { arrival or at arrival and } 14 \\
\text { days later }\end{array}$ & $\begin{array}{l}\text { Genetically attenuated } \\
\text { leukotoxin of } M \text {. } \\
\text { haemolytica combined } \\
\text { with bacterial extracts } \\
\text { of } M \text {. haemolytica }+H \text {. } \\
\text { somni/1 or } 2 \text { SQ or IM } \\
\text { doses }\end{array}$ & $\begin{array}{l}\text { BRD Morbidity: RR=0.37 (0.24-0.56) } \\
\text { Tx: } 29 / 198 \\
\text { Control: } 41 / 103 \\
\text { BRD Mortality: RR=NA } \\
\text { Tx: } 0 / 198 \\
\text { Control: } 2 / 103\end{array}$ \\
\hline
\end{tabular}




\begin{tabular}{|l|l|l|l|}
\hline \multicolumn{3}{|c|}{ Histophilus somni vaccine studies } \\
\hline $\begin{array}{l}\text { Amstutz et al. } \\
\text { Bov Pract 1981 }\end{array}$ & $\begin{array}{l}\text { Random allocation of } \\
\text { beef heifers vaccinated at } \\
\text { feedlot arrival and 21 } \\
\text { days later }\end{array}$ & $\begin{array}{l}\text { H. somni bacterin / } 2 \\
\text { IM doses }\end{array}$ & $\begin{array}{l}\text { BRD Morbidity: RR=0.64 (0.40-1.03) } \\
\text { Tx: 21/106 } \\
\text { Control: 33/107 } \\
\text { BRD Mortality: RR=NA } \\
\text { Tx: 3/106 } \\
\text { Control:2 /107 }\end{array}$ \\
\hline $\begin{array}{l}\text { Morter and } \\
\text { Amstutz Bov } \\
\text { Pract 1983 }\end{array}$ & $\begin{array}{l}\text { Random allocation of } \\
\text { crossbred steers } \\
\text { vaccinated at feedlot } \\
\text { arrival }\end{array}$ & $\begin{array}{l}\text { H. somni bacterin / 1 } \\
\text { IM dose } \\
\text { BRD Morbidity: RR=1.44 (1.03-2.03) } \\
\text { Tx: 49/102 } \\
\text { Control: 34/102 }\end{array}$ \\
\hline $\begin{array}{l}\text { Morter and } \\
\text { Amstutz Bov }\end{array}$ & $\begin{array}{l}\text { Random allocation of } \\
\text { crossbred steers } \\
\text { vaccinated at feedlot } \\
\text { arrival and 21 days later }\end{array}$ & $\begin{array}{l}\text { H. somni bacterin / 2 } \\
\text { IM doses }\end{array}$ & $\begin{array}{l}\text { BRD Morbidity: RR=0.91 (0.61-1.36) } \\
\text { Tx: 31/102 } \\
\text { Control: 34/102 }\end{array}$ \\
\hline
\end{tabular}


Appendix 2. Articles reviewed for the evaluation of effectiveness of commercially available vaccines against Mannheimia haemolytica, Pasteurella multocida and/or Histophilus somni in feedlot cattle using an induced disease model with lung lesions or other measures of disease severity reported as an outcome.

\begin{tabular}{|c|c|c|c|}
\hline Reference & Study Design & Vaccine & Outcome \\
\hline \multicolumn{4}{|c|}{ Mannheimia. haemolytica vaccine studies } \\
\hline $\begin{array}{l}\text { Confer and } \\
\text { Fulton Bovine } \\
\text { Proceedings } \\
1994\end{array}$ & $\begin{array}{l}\text { Unknown allocation of } 136-205 \\
\text { kg beef calves vaccinated twice } \\
\text { at } 21 \text { day interval prior to } \\
\text { transthoracic } M \text {. haemolytica } \\
\text { challenge } 14 \text { days after last } \\
\text { vaccination }\end{array}$ & $\begin{array}{l}\text { M. haemolytica } \\
\text { bacterin-solubilized } \\
\text { surface antigens }\end{array}$ & $\begin{array}{l}25 \% \text { of control calves died and } \\
\text { surviving cattle developed moderate } \\
\text { to severe pneumonia while } \\
\text { vaccinated cattle had transient } \\
\text { clinical signs of BRD and no deaths. } \\
\text { Pulmonary lesions for vaccinates } \\
\text { were } 64.5-71.4 \% \text { less than for } \\
\text { controls }\end{array}$ \\
\hline $\begin{array}{l}\text { Confer and } \\
\text { Fulton Bovine } \\
\text { Proceedings } \\
1994\end{array}$ & $\begin{array}{l}\text { Unknown allocation of calves } \\
\text { vaccinated once prior to } \\
\text { transthoracic M. haemolytica } \\
\text { challenge }\end{array}$ & $\begin{array}{l}\text { M. haemolytica } \\
\text { bacterin-toxoid } \\
\text { (chemically } \\
\text { inactivated culture } \\
\text { of multiple isolate of } \\
\text { M. haemolytica) }\end{array}$ & $\begin{array}{l}80 \% \text { of control cattle and } 10 \% \text { of } \\
\text { vaccinated cattle died following } \\
\text { challenge. All control calves had } \\
\text { severe pneumonia. The surviving } \\
\text { vaccinated cattle had transient } \\
\text { clinical signs of BRD. Pulmonary } \\
\text { lesions for vaccinates were 52.5-53\% } \\
\text { less than for controls }\end{array}$ \\
\hline $\begin{array}{l}\text { Confer et al. } \\
\text { Vaccine } 2003\end{array}$ & $\begin{array}{l}\text { Unknown allocation of weaned } \\
\text { beef steers vaccinated once } \\
\text { prior to transthroacic challenge } \\
\text { with } 3.0 \text { x } 109 \text { CFU M. } \\
\text { haemolytica } 24 \text { days later }\end{array}$ & $\begin{array}{l}\text { Inactivated } M \text {. } \\
\text { haemolytica, } \\
\text { bacteria-free extract } \\
\text { with leukotoxoid } \\
\text { and bacterial surface } \\
\text { subunit antigens /2 } \\
\text { IM doses }\end{array}$ & $\begin{array}{l}\text { At necropsy, mean lung lesion scores } \\
\text { were } 7.9 \pm 3.6 \text { for non-vaccinated } \\
\text { controls and } 3.0 \pm 1.3 \text { for vaccinates } \\
\text { (62.0\% reduction in lesion score) }\end{array}$ \\
\hline $\begin{array}{l}\text { Loan et al. Bov } \\
\text { Pract } 1989\end{array}$ & $\begin{array}{l}\text { Unknown allocation of } 182-227 \\
\mathrm{~kg} \text {. cattle vaccinated twice at } 28 \\
\text { day interval and challenged via } \\
\text { transthoracic inoculation with } \\
\text { M. haemolytica } 7 \text { days after last } \\
\text { vaccination }\end{array}$ & $\begin{array}{l}\text { Bacterin (tissue } \\
\text { culture-derived } M . \\
\text { haemolytica } \\
\text { bacterin)/ } 2 \text { IM } \\
\text { doses }\end{array}$ & $\begin{array}{l}\text { More vaccinated calves survived } 4 \\
\text { days post challenge than controls } \\
\text { (14/18 vs. 0/18) and at necropsy } 4 \\
\text { days post challenge, control calves } \\
\text { had lung lesions that averaged } 831 \\
\mathrm{~cm}^{3} \text { while vaccinated calf lung } \\
\text { lesions averaged } 58 \mathrm{~cm}^{3}\end{array}$ \\
\hline $\begin{array}{l}\text { Loan et al. Bov } \\
\text { Pract } 1989\end{array}$ & $\begin{array}{l}\text { Unknown allocation of calves } \\
\text { vaccinated at } 1 \text { to } 4 \text { month of } \\
\text { age and returned to their dams, } \\
\text { vaccinated again } 3 \text { months later } \\
\text { and challenged via } \\
\text { transthoracic inoculation with } \\
\text { M. haemolytica } 7 \text { days after last } \\
\text { vaccination }\end{array}$ & $\begin{array}{l}\text { Bacterin (tissue } \\
\text { culture-derived } M \text {. } \\
\text { haemolytica } \\
\text { bacterin)/ } 2 \text { IM } \\
\text { doses }\end{array}$ & $\begin{array}{l}\text { More vaccinated calves survived } 4 \\
\text { days post challenge than controls ( } 8 / 8 \\
\text { vs. } 1 / 8 \text { ) }\end{array}$ \\
\hline
\end{tabular}


Appendix 3. Articles reviewed for the evaluation of effectiveness of commercially available vaccines against Mannheimia haemolytica, Pasteurella multocida and/or Histophilus somni in dairy or beef calves using natural disease challenge with cumulative morbidity risk and/or cumulative mortality risk reported as an outcome.

\begin{tabular}{|c|c|c|c|}
\hline Reference & Study Description & Vaccine & Risk Ratio (95\% CI) \\
\hline \multicolumn{4}{|c|}{ Mannheimia. haemolytica and M. haemolytica + Pasteurella multocida vaccine studies } \\
\hline $\begin{array}{l}\text { Aubry et al. } \\
\text { JAVMA } 2001\end{array}$ & $\begin{array}{l}\text { Paired (sequentially by } \\
\text { birth date) allocation of } \\
\text { Holstein heifer calves first } \\
\text { vaccinated at } 14 \text { and } 20 \\
\text { days of age and again } 14 \\
\text { days later }\end{array}$ & $\begin{array}{l}\text { Avirulent live culture of } M \text {. } \\
\text { haemolytica and } P \text {. } \\
\text { multocida/2 IM doses }\end{array}$ & $\begin{array}{l}\text { BRD Morbidity: } \mathbf{R R}=\mathbf{1 . 0 0}(\mathbf{0 . 6 4}- \\
\text { 1.56) } \\
\text { Tx: } 32 / 179 \\
\text { Control: } 32 / 179 \\
\text { Crude Mortality: RR=0.86 (0.29- } \\
\text { 2.50) } \\
\quad \text { Tx:6/179 } \\
\text { Control: } 7 / 179\end{array}$ \\
\hline $\begin{array}{l}\text { Smith et al. Vet } \\
\text { Med } 1985\end{array}$ & $\begin{array}{l}\text { Unknown allocation of } \\
\text { dairy bull calves } \\
\text { vaccinated once at two } \\
\text { weeks of age (1984 } \\
\text { vaccinates) }\end{array}$ & $\begin{array}{l}\text { Live culture of } M \text {. } \\
\text { haemolytica / ID dose }\end{array}$ & $\begin{array}{l}\text { BRD Morbidity: RR=0.55 (0.41- } \\
\text { 0.74) } \\
\text { Tx: } 31 / 73 \\
\text { Control: } 59 / 77\end{array}$ \\
\hline $\begin{array}{l}\text { Smith et al. Vet } \\
\text { Med } 1985\end{array}$ & $\begin{array}{l}\text { Unknown allocation of } \\
\text { dairy bull calves } \\
\text { vaccinated once at two } \\
\text { weeks of age (1985 } \\
\text { vaccinates) }\end{array}$ & $\begin{array}{l}\text { Live culture of } M \text {. } \\
\text { haemolytica /1 ID dose }\end{array}$ & $\begin{array}{l}\text { BRD Morbidity: RR=0.62 (0.47- } \\
\mathbf{0 . 8 2 )} \\
\quad \text { Tx: } 34 / 74 \\
\text { Control: } 58 / 78 \\
\text { Crude Mortality: RR=0.21 (0.05- } \\
\text { 0.93) } \\
\quad \text { Tx: } 2 / 74 \\
\text { Control: } 10 / 78 \\
\end{array}$ \\
\hline \multicolumn{4}{|c|}{ Mannheimia. haemolytica + Histophilus somni vaccine studies } \\
\hline $\begin{array}{l}\text { Van } \\
\text { Donkersgoed et } \\
\text { al. Can Vet J } \\
1994\end{array}$ & $\begin{array}{l}\text { Systematic allocation of } \\
\text { beef calves vaccinated at } 3 \\
\text { weeks and again at } 5 \\
\text { weeks of age }\end{array}$ & $\begin{array}{l}\text { Genetically attenuated } \\
\text { leukotoxin of } M \text {. } \\
\text { haemolytica combined } \\
\text { with bacterial extracts of } \\
M \text {. haemolytica }+H \text {. } \\
\text { somni/1 or } 2 \text { SQ or IM } \\
\text { doses }\end{array}$ & $\begin{array}{l}\text { BRD Morbidity: RR=1.04 (0.51- } \\
\text { 2.10) } \\
\text { Tx: } 10 / 28 \\
\text { Control: } 10 / 29\end{array}$ \\
\hline $\begin{array}{l}\text { Van } \\
\text { Donkersgoed et } \\
\text { al. Can Vet J } \\
1994\end{array}$ & $\begin{array}{l}\text { Systematic allocation of } \\
\text { beef calves vaccinated at } 3 \\
\text { weeks and again at } 5 \\
\text { weeks of age }\end{array}$ & $\begin{array}{l}\text { Genetically attenuated } \\
\text { leukotoxin of } M \text {. } \\
\text { haemolytica combined } \\
\text { with bacterial extracts of } \\
\text { M. haemolytica }+H \text {. } \\
\text { somni/1 or } 2 \text { SQ or IM } \\
\text { doses }\end{array}$ & $\begin{array}{l}\text { BRD Morbidity: RR=0.44 (0.16- } \\
\text { 1.25) } \\
\text { Tx: } 4 / 26 \\
\text { Control: } 10 / 29\end{array}$ \\
\hline
\end{tabular}

